\title{
University Innovation Hubs \& Technology-Enhanced Learning in K12 Environments
}

\author{
Josh Herron $^{1}$ (D) Kathryn A. Wolfe ${ }^{1}$ \\ Accepted: 17 December 2020 / Published online: 16 January 2021 \\ (C) Association for Educational Communications \& Technology 2021
}

\begin{abstract}
Colleges and schools of education serve K12 educators very well in many areas and there are instructional design programs housed in traditional academic units that produce high-caliber scholars and researchers that impact our field. However, this article suggests that partnerships between university innovation hubs and K12 schools fill a gap of programming focused on developing practical skills related to digital transformation of learning environments. This article presents a case study of an innovation hub developing such programming. Anderson University (SC)'s Center for Innovation and Digital Learning (CIDL) staff began offering external professional development offerings for K12 educators and leaders who were seeking to use design thinking and emerging technologies as the university had been doing with its own initiatives, such as its one-to-one program. Over time, these relationships led to the development of a uniquely structured professional master's degree intentionally aligned to national K12 and post-secondary educational technology association standards as well as state online teacher endorsement criteria. The program is administered and taught by instructional design personnel in the CIDL, a university innovation hub outside of a traditional academic unit. The article offers insight into the development and alignment of external programming as well as specific insights from the learners, instructors, and the program leaders: (1) the importance of having practitioners as faculty in digital transformation programs; (2) the role of practitioner-faculty in professional community development; and (3) the organizational advantages and impact. Implications and further research opportunities around this type of programming will be identified as well.
\end{abstract}

Keywords Instructional design $\cdot$ Learning technology $\cdot$ K12 digital learning $\cdot$ Digital transformation graduate programs

In early Gonzalez 2020, Jennifer Gonzalez, who runs cultofpedagogy.com, a site dedicated to K12 classroom pedagogy, tweeted out to her 134,000 followers that she had only recently "learned about a field of study called Instructional Design that somehow had no relationship with schools of teacher education. This field has GOBS of theory and systems and a whole vocabulary that preservice teachers know nothing about. How can this be?" Her thread of Tweets continues, noting that disconnect between teacher education and instructional design. Despite creative approaches to teaching and learning that are often borne of necessity in

Josh Herron

jherron@andersonuniversity.edu

Kathryn A. Wolfe

kwolfe@andersonuniversity.edu

1 Anderson University (SC), Anderson, SC, USA
K12 classrooms, some of which make use of digital tools, online and digital learning has been slow to transform K12 education in the way it has for higher education. Online learning in the K12 context has not had the length of research as higher education and has largely been relegated to a credit recovery mechanism (Picciano and Seaman 2007). The study of instructional design, a core element of digital learning transformation, has not permeated teacher education programs. There have also been no major examples of practitioner-based programs in instructional design and learning technology that draw a majority of K12 teachers seeking to engage in the student of digital transformation of their teaching and learning environments.

Online and digital learning has more significantly impacted the structure of higher education, however, and served as a catalyst for further innovation (Wilcox et al. 2016). The growth of centers dedicated to online, digital, and/or innovative learning approaches has grown during this time as Centers for Teaching and Learning merge with information 
technology in the development of academic innovation centers (Bishop and Keehn 2015). Most teacher preparation departments in colleges and schools of education are largely being taught by those who had spent their time working or studying in the K12 environments, which had not had some of the disruptions of higher education. In fact, many of the staff working in these digital learning and innovation centers are not from an education background, so there has not been a clear relationship on campuses where these hubs have been emerging to transform post-secondary teaching and learning practices (Mancilla and Frey 2020).

Instructional design is a key component of digital transformation in higher education. Although the function of instructional designers has been around since World War II, the roles and field continues to transform and grow as societal and technological needs change. Fyle et al. (2012) state at most universities, instructional designers' roles are focused in three main areas: "pedagogy; planning, project management, administration and logistics; and appropriate use of media and technology" (p. 57). Additionally, the authors explain that the role of instructional designers is that of "support services" which is often misunderstood (Fyle et al. 2012, p. 54). Similarly, these authors discuss how instructional designers are instrumental in "transforming learning in higher education" as well as "change agents" (Fyle et al. 2012, p. 57). Clearly, instructional designers bring valuable skills to their organizations and practical experience to higher education that are desired by others as they see their impact.

While the role of instructional design is now being understood as necessary in higher education, it has been slow to permeate the K12 learning environment. Shari Smith (2011) states, "The instructional designer has the potential to significantly assist a school in teaching and learning, and therefore provide benefits for both the learners and fellow faculty" (p. 2). The author goes on to state that instructional designers are typically not seen in these educational environments. Even without wholesale digital learning transformation taking place, most K12 districts and schools seem to intuitively know they need to purchase Chromebooks, iPads, 3D printers, and other emerging technologies to support twenty-first Century Learning; however, they have not been integrated into a larger design of the K12 educational system, largely due to a lack of a focus on the role of instructional design.

At the same time, the teaching profession has undergone a change that requires technology to be an integral part of professionalization, but with little clarity around the learning design or digital transformation expectations (Shaffer et al. 2015). As K12 teachers and leaders have begun recognizing the impact of a digital society beyond a tool-based approach to technology, they cannot continue to look only to teacher preparation faculty for insight on digital transformation or even classical instructional design programs. Thus, these burgeoning centers for digital learning are becoming another area of outreach and programming for K12 schools when seeking support for comprehensive technology integration.

The accelerated move to remote and hybridized learning during the 2020-21 pandemic will likely accelerate the development of relationships for innovation hubs in higher education: "At their peak, [school] closures affected at least 55.1 million students in 124,000 U.S. public and private schools. Nearly every state either ordered or recommended that schools remain closed through the end of the 2019-20 school year" (Education Week 2020). Thus, more districts will become aware that there is a need to identify the transformative aspects of instructional design and learning technology instead of just the additive elements of it to classroom experiences.

In addition to those working in K12 education looking to innovation hubs for digital transformation expertise, those staff members have also been developing their own professional competencies. As mentioned, many digital learning practitioners in higher education do not have formal degrees in the field and many with degrees outside of education. Yet, as the professionalization of the instructional design role has developed due to the "external pressure for instructional designers to innovate, investigate, and publish on digital learning and technologies," there has also been an increasing need to codify those skills and package them in a formal program (Kilgore et al. 2019). The professionalization of the role that innovation and digital learning hub staff members are experiencing for themselves directly influence the ability to develop offerings to prepare practitioners for the digital transformation that is occurring in $\mathrm{K} 12$ - as well as higher education and all industries navigating the fourth industrial revolution and the future of work that will require constant retraining and upskilling.

\section{Methodology}

In order to capture the unique creation and development of the external programming developed by Anderson University's Center for Innovation and Digital Learning staff, and the perspectives of those involved, the participant-researchers employed a case study design. This case study was bound by the M.S. Instructional Design and Learning Technology (IDLT) program at Anderson University and it examined the origin and development of this uniquely situated program within the Center for Innovation and Digital Learning as the staff are practitioner-faculty members working in multiple roles. While the first cohort for this program began their courses in January 2019, the University processes for approval to get this program up and running began about a year prior. Moreover, in hopes of providing the most recent and up to date information, all data gathered about this case study went through October of 2020. Therefore, this case study examines the genesis, launch, and growth of M.S. IDLT program from 
roughly spring semester of 2018 through fall semester of 2020.

This case study was analyzed by participant-researchers who sought to understand this distinctive program which allowed them to "gain an in-depth understanding of the situation and meaning for those involved" (Merriam 1998, p. 19). Additionally, it provided the opportunity to gain understandings and allowed for "descriptions and analyses..." on a specific part (Merriam 1998, p. 19). The purpose of this study was to investigate the impact of an new program, the M.S. Instructional Design and Learning Technology, on recent graduates and current instructors; therefore, the participantresearchers facilitated the use of a mixed-methods approach through the use of a convergent design. By working within a convergent design, they were able to use both quantitative and qualitative methodologies (Creswell and Plano Clark 2011) to look at this case study.

\section{Participant-Researchers}

This case study examines the creation, design, and development of an innovative professional master's program within a university unit. It was essential that those involved in this process were part of describing its development and current state. Therefore, a self-study methodology was utilized in order to grasp the origin and metamorphosis of this program. Self-studies are often employed to understand and examine programs. Additionally, unlike other studies "we did not claim objectivity but rather positioned validity within the constructs of 'our discourse and actions"' (Taylor et al. 2014, p. 4). It was vital that the researchers were also participants in this study because their insight into this case study is instrumental as they are the Program Director and Assistant Program Director, respectively. In these roles, the Program Director saw the origin, institutional approval, formation, and debut of the new program. The Assistant Program Director came to the program in its third semester and worked on course and program alignment, honing curricular tracks, and developing student engagement opportunities. Within these roles, and as participant-researchers for this case study, they aim to provide insight into this uniquely situated and continuously growing program.

\section{Quantitative}

The quantitative data for this study was collected from two different surveys. Upon completion of their last course, M.S. in Instructional Design and Learning Technology alumni are invited to complete a survey via Qualtrics about their experience in the program. Questions in the survey inquire about their overall satisfaction in the program, the sense of professional community, and the role that the courses and professors had in their program experience. There were two free response questions which provided insight into overall program and the alumni's future plans and were used in the qualitative analysis. A second survey was sent to the current M.S. IDLT instructors. This survey's focus was to examine overlap between the instructors and their primary roles as learning designers, the workload impact of teaching in the program, and the professionalization of instructors by participating in the program. Once both sets of quantitative data were collected, the participant-researchers analyzed the data by performing descriptive statistics noting the patterns and frequencies in both groups' responses. This provided them with insight into alumni's program experiences and instructors' views of the program and their roles.

\section{Qualitative}

While the participant-researchers' understandings guided the overall narrative to this case study, they recognize the importance of including the voice of as many individuals involved in the program as possible. Some qualitative data from alumni was gathered from the free response survey questions. However, the largest amount of insight was collected from the current M.S. IDLT instructors. The survey that was sent to the instructors included five Likert-type questions which provided quantitative data and was followed up with five open-ended questions that provide rich data from the instructors.

In order, to capture the collective narrative from all of the instructors in the program, the participant-researchers employed a collaborative autoethnographic approach for the qualitative analysis. Since the researchers were participants within the study, the use of a collaborative autoethnography afforded them the opportunity to capture the insights of each individual and then provide a collective perspective and voice. Moreover, many collaborative autoethnographies (CAE) are employed when conducting a "self-study", especially in regard to programs and program reviews (Hains-Wesson and Young 2017; Taylor et al. 2014). Since this study aimed at exploring the influence of this newly formed M.S. IDLT program, the CAE approach allowed the participant-researchers the freedom to "interpret their data collectively to gain a meaningful understanding..." (Chang et al. 2013, p. 23-24). This provided the participant-researchers the opportunity to have their narratives be part of the data and analysis.

\section{The Case Study}

\section{The Center for Innovation and Digital Learning at AU}

The particular innovation and digital learning hub of focus in this article is the Center for Innovation and Digital Learning (CIDL) at Anderson University (SC). The CIDL launched in 
2014 as a formalized way to support the Mobile Learning Initiative on campus as well as the University's growing online programs. With its focus on digital transformation, the university experienced an enrollment boom and period of growth in academic programming. The university, and the CIDL, became recognized as a leader in integrating educational technology among its peers, earning distinctions such as Most Innovative School ranking by U.S. World News and Report, three-time Apple Distinguished School, and other accolades from the Online Learning Consortium, UPCEA, and Eduventures. The CIDL became the centralized, strategic approach to faculty development and learning technologies support and has been key in reaching these recognitions. The mission of the Center for Innovation and Digital Learning is to provide high quality, learner-centered online and blended courses; to foster, support, and promote excellence in online and blended learning and teaching; to enrich teaching and learning through innovative practices and technologies; to promote and support the development of active, engaged learning experiences in traditional, online, and blended learning environments; to make learning accessible to students in all curricular and co-curricular aspects of the university; and to enable institution-wide engagement that supports academic success and student development (Internal document).

Executing this mission was initially up to three instructional designers when the CIDL launched in 2014. The staff size has since grown to eight personnel who support the design and delivery of online, mobile, and blended programs, and only one with a formal degree in instructional design. The background academic work ranges from English and communication, curriculum and instruction, graphic design, and interdisciplinary studies. The CIDL staff used previous experiences and their various academic training to move into instructional design roles. Their own professional development and pivot toward these roles prepared them to not only support faculty without experience in instructional design, but to ultimately develop non-credit and credit programs as is the focus of this case study.

\section{Initial K12 Educator Programming}

The Center for Innovation and Digital Learning (CIDL) at Anderson University (SC) developed a reputation as a resource for the latest in digital learning among its area K12 leaders and teachers across a number of years. From 2012 to 2016, the Center was recognized as a South Carolina Center of Excellence for Mobile Learning, offering training and development experiences to local districts on the concept of digital transformation leveraging the experience of supporting the university's one-to-one mobile learning initiative. Further, given the relationship that the university had with Apple, involvement on initiatives such as Everyone Can Code and Everyone Can Create naturally extended to K12 teacher workshops coding and computational thinking, eventually expanding further based on feedback from participants to included sessions on makerspaces, emerging technology, and design thinking. The relationship fostered through these experiences had a seminal role in the launch of the M.S. IDLT degree program, which was proposed to the university and accrediting body in 2017, using these experiences as part of the rationale.

The CIDL continues to offer non-credit professional development programming for K12 teachers, including during the 2020 coronavirus pandemic. As noted in the background section, school districts' move to remote learning in 2020 has the potential to accelerate the relationship development of innovation hubs in higher education and districts as instructional design and learning technology becomes less of a bolt-in addition to more of a true transformation of learning environments. Responding to the needs that local and regional districts were citing in Spring 2020 the Center for Innovation and Digital Learning expanded its programming by creating the professional development webinar, "10 Tips to Be a Rockstar Online Educator." This webinar provided teachers with tips and resources as they found themselves quickly switching to remote teaching. With over 150 teachers and educational professionals registered, the CIDL offered insight into the world of remote teaching, online best practices, and technology resources.

The CIDL received positive feedback from both teachers and administrators and saw that there was additional need for K12 educators. In response, the CIDL staff created self-paced professional training certifications in Spring and Summer 2020. The first, "Fundamentals of Remote Teaching and Learning," provides a foundation to remote education in which participants create a robust resiliency plan of their own. The second, "Supporting Remote Teachers," was created for school administrators and staff as they learn strategies to support teachers in remote learning. Over 100 educators have enrolled in these two trainings, so a third training was developed in late Summer 2020, "Differentiating Instruction in Remote Environments." During the periods of remote learning throughout 2020, the CIDL team was able to adapt and respond to just-in-time learning needs for the community by adjusting the program's courses to meet the needs of teachers and trainers using the experiences that the CIDL staff members were doing themselves while transitioning the university's faculty, courses, and students to a remote teaching environment.

\section{M.S. in Instructional Design and Learning Technology}

Building on the years of relationship development by the Center for Innovation and Digital Learning with K12 education partners, a credit-bearing program was developed in the unit as a professional Master of Science in Instructional 
Design and Learning Technology (M.S. IDLT), a fully online program. The K12 educators seeking to learn about digital transformation and tools from non-credit programs offered by the center were seeking to develop skills further in a full degree program. The uniquely situated degree program is taught and administered by the staff in the university's Center Innovation and Digital Learning (CIDL) to intentionally connect the work of transformational teaching and learning happening in the innovation hub to learners' experiences.

Nationally and regionally, an increase in the online and blended learning modality in K-12 and higher education environments in university's state and region pointed to a growing need for professionals who are able to design and deliver courses in these environments (Allen and Seaman 2017). Even outside just online or blended learning, the growth of one-to-one technology programs in districts across South Carolina have placed a need for trained staff and faculty at the building and district level. Both of these were particular strengths that Anderson University had as it was seeing significant growth in the offering of online and blended programming as well as having been recognized three times as an Apple Distinguished School for its digital learning initiative, which included one-to-one devices for students and faculty (Poovey 2016; Campbell 2015).

By developing intentional relationships with learning design and technology counterparts at school districts and organizations with instructional design units, the M.S. IDLT program leaders formed an advisory board in Spring 2018, a year before the program launch. Representatives came to campus for an initial meeting and echoed a significant need for this type of degree and the ability of Anderson University to fill a gap that they were seeing in comprehensive digital transformation. Their feedback aligned with the market research performed by program leaders in noting that there was a $6 \%$ expected job growth associated with the particular roles in K12 environments ("Instructional Coordinators") and a master's degree had become the typical entry-level education for this role according to the Bureau of Labor Statistics (2020). Three distinct goals were developed for the program. Graduates of this program will be able to:

1. Apply best practices in instructional design to solve authentic instructional design problems and challenges.

2. Develop instructional materials by applying instructional design theory and principles with the support of instructional technology.

3. Integrate and evaluate emerging technologies and modes of learning in support of desired learning outcomes (Internal documents).

Ten courses are offered in the program with certain program-level goals tied to each. All students are required to begin the program with a course in foundational instructional design and learning theories (IDLT 500) in order to have a framework to apply to the remaining courses. The remaining courses then have students apply these frameworks and theories to various contexts and environments. The final course for a student is the Learning Design Studio (IDLT 600). In this course, students create a portfolio that reflects the outcomes of the program along with a project that combines the work of the other courses. All of the courses leading up to the final course are designed to prepare students for this culminating experience.

The M.S. in Instructional Design and Learning Technology program began the spring semester of 2019 with its first cohort of 11 students. Students can begin the M.S. IDLT program in the fall, spring, or summer. At present, there are 72 active students in the program with roughly $85 \%$ coming from a K12 background, with many being current classroom teachers. There have been 20 graduates.

The only example that the CIDL was able to point to of an innovation hub offering a degree was the M.A. in Learning, Design, and Technology offered by Georgetown University's Center for New Designs in Learning and Scholarship (CNDLS). Similar to the setup of the M.S. IDLT program being described in this article, the founding director at Georgetown described their program this way:

We're [...] not in a school of education. We are coming at this slightly from the side. The work of CNDLS is intimately connected to this grad program. The faculty in my center will be teaching in the program. We'll have this kind of dynamic where it is actually evolving from practitioners who are doing work and research in higher ed. It's like if a School of Library Information were to actually run the library. (Cortez 2016)

While the program at Georgetown is more focused on higher education professionals, the precedence of offering a degree focused on digital transformation in an innovation hub was established there in 2016. The M.S. IDLT program at Anderson University is largely K12 educator focused as opposed to the higher education focus of Georgetown's program.

\section{M.S. IDLT as University-School Partnership}

There are certainly formalized school-university partnerships similar to the one described in the development of the M.S. IDLT program in consultation with the area school districts, such as Professional Development Schools (PDS) as defined by the National Association of Professional Development Schools (NAPDS n.d.) in their "9 Essentials" of collaborations. However, these formalized partnerships have typically been found in colleges or schools of education. This program was developed in a university innovation hub in a largely ad- 
hoc fashion through individual networking with school districts.

The M.S. IDLT external advisory board meets regularly to provide feedback on the program and hear updates. In the first advisory board meeting, the CIDL staff and members worked together to determine objectives, activities, and assessments for the program based on the digital transformation work that happens in the CIDL and what the districts and employers are hoping to see accomplished by graduates in the program. The coursework for this program includes all new courses in order to align with current and future needs of educators and trainers, developed in close cooperation with the advisory board members. While some similar programs use existing education courses as part of the program's curriculum, our method was to create all new experiences given the unique approach that learners were seeking through a program taught that would be focused on practical skills related to designing instruction and integration technology given that it was to be administered by an innovation hub with practitioner-faculty rather than solely in a College of Education.

Upon guidance of the advisory board and recognizing that K12 teachers and districts would be a significant part of this program, the curriculum was designed to align with Association for Educational Communications and Technology (AECT) initial standards; International Society for Technology in Education (ISTE) standards for coaches; and South Carolina Online Teaching Endorsement requirements. The alignment of these standards is shown in Table 1.

The CIDL continues to obtain insight as to the needs for trainings and learning opportunities district leaders would like for their teachers despite not having a formalized PDS relationship.

\section{Analysis \& Discussion}

When the Center for Innovation and Digital Learning (CIDL) decided to expand beyond its fairly impromptu external programming of workshops leading to teacher recertification credits to the M.S. IDLT program, it found that while it filled a gap in area degree offerings, reframing the innovation hub as a programmatic resource created unique structural and operational considerations. Although the external demand was clearly present, the internal challenges required some reimagining of processes to serve both internal and external constituents well. Specifically, offering external programming from a support center requires important workload considerations. Because the staff who teach in the program receive overload pay, there is a sense that it is above and beyond even if it's still viewed as a central part of the department. While it is intentional and necessary to have staff in the innovation hub design, facilitate, and coordinate external offerings, it comes with the tension of seeing it as part of the larger purpose of the unit without creating burnout from normal duties. Further, for staff who cannot or choose not to participate in teaching or designing courses, there must also be a clear delineation so that work on the programmatic offering side does not lead to issues when the opportunity is not afforded or desired by everyone in the office.

For those who do teach in the program, toggling the work of an instructional designer and subject matter expert does require a delicate balance, but the challenges are accompanied by opportunities that make the endeavor worthwhile. Using data from a recent survey of M.S. IDLT faculty and alumni, three key considerations were identified from the offering of $\mathrm{a}(\mathrm{n})$ external program(s) focused on digital transformation within an innovation hub to serve audiences such as K12 educators not being served by traditional academic units: (1) the importance of having practitioners as faculty in digital transformation programs; (2) the role of practitioner-faculty in professional community development; and (3) the organizational advantages and impact.

\section{Importance of Practitioners as Faculty in Digital Transformation Programs}

The importance of having CIDL staff as faculty members for the M.S. IDLT program is key to its success. Both students and alumni underscore the importance of faculty members who are actively involved in this field. A common refrain regarding digital learning is that technology is constantly changing, and practicing instructional designers are charged with not only remaining up-to-date but being able to enact these changes. For example, in the last decade, the staff in the CIDL have been responsible for initiating and supporting a mobile learning initiative, makerspace, media studio, and increased online and blended learning offerings.

Further, during the 2020-21 academic year, the CIDL was home-base for training faculty and supporting remote and hybridized learning brought on by a pandemic. This included the introduction of new modalities and approaches, such as Hyflex. Having conducted the research and experienced the implementation of these endeavors, the instructional designers are best suited to help prepare external audiences through professional development offerings or a professional master's program such as the M.S. IDLT.

Many K12 teachers are also intentionally seeking a professional master's program where they can learn practical, research-based material around digital learning in ways not available to them in their districts. In fact, the M.S. IDLT program saw increased enrollment during the pandemic of 2020-21, and many new students in K12 education environments cited the lack of digital learning support during the pandemic as a reason for enrolling. Further, graduates from the first cohorts of the M.S. in IDLT program noted the importance of having faculty who were active instructional 
Table 1 Alignment of courses to state \& national standards

\begin{tabular}{|c|c|c|c|}
\hline Course & Association for educational communications and technology & ISTE alignment for coaches & $\begin{array}{l}\text { SC online teaching } \\
\text { endorsement }\end{array}$ \\
\hline $\begin{array}{l}\text { IDT 500: Instructional } \\
\text { Design and Innovation } \\
\text { ( } 3 \text { credits })\end{array}$ & $\begin{array}{l}\text { Design: Instructional Design Systems (1.1), Message Design } \\
\text { (1.2), Instructional Strategies (1.3), Learner Characteristics } \\
\text { (1.4) }\end{array}$ & $\begin{array}{l}\text { 2. Teaching, learning, and } \\
\text { assessments }\end{array}$ & $\begin{array}{l}\text { Instructional Design and } \\
\text { Assessment }\end{array}$ \\
\hline $\begin{array}{l}\text { IDT 501: Designing } \\
\text { Future Learning } \\
\text { Environments } \\
(3 \text { credits })\end{array}$ & $\begin{array}{l}\text { Utilization: Media Utilization (3.1), Diffusion of Innovations } \\
\text { (3.2), Implementation and Institutionalization (3.3), } \\
\text { Policies and Regulations (3.4) }\end{array}$ & 1. Visionary Leadership & \\
\hline $\begin{array}{l}\text { IDT 502: Research } \\
\text { Design and Methods } \\
\text { for IDT ( } 3 \text { credits) }\end{array}$ & $\begin{array}{l}\text { Evaluation: Problem Analysis (5.1), Criterion-Referenced } \\
\text { Management (5.2) }\end{array}$ & $\begin{array}{l}\text { 2. Teaching, learning, and } \\
\text { assessments }\end{array}$ & \\
\hline $\begin{array}{l}\text { IDT 510: Mobile } \\
\text { Learning ( } 3 \text { credits) }\end{array}$ & $\begin{array}{l}\text { Design: Learner Characteristics (1.4) Development: } \\
\text { Integrated Technologies (2.4) Management: Resource } \\
\text { Management (4.2) }\end{array}$ & $\begin{array}{l}\text { 3. Digital age learning } \\
\text { environments }\end{array}$ & $\begin{array}{l}\text { Internet Safety for Online } \\
\text { Learnings }\end{array}$ \\
\hline $\begin{array}{l}\text { IDT 511: Learning } \\
\text { Analytics ( } 3 \text { credits) }\end{array}$ & $\begin{array}{l}\text { Management: Information Management (4.4) Evaluation: } \\
\text { Problem Analysis (5.1), Criterion-Referenced } \\
\text { Management (5.2) }\end{array}$ & $\begin{array}{l}\text { 2. Teaching, learning, and } \\
\text { assessments }\end{array}$ & \\
\hline $\begin{array}{l}\text { IDT 512: Program } \\
\text { Development and } \\
\text { Evaluation ( } 3 \text { credits) }\end{array}$ & $\begin{array}{l}\text { Design: Instructional Systems Design (1.1) Management: } \\
\text { Project Management (4.1) Evaluation: Formative } \\
\text { Evaluation (5.3), Summative Evaluation (5.4) }\end{array}$ & $\begin{array}{l}\text { 4. Professional development } \\
\text { and program evaluation }\end{array}$ & $\begin{array}{l}\text { Knowledge of Utilizing } \\
\text { Online Learning } \\
\text { Management Systems }\end{array}$ \\
\hline $\begin{array}{l}\text { IDT 520: Current Issues } \\
\text { and Trends ( } 3 \text { credits) }\end{array}$ & & 5. Digital citizenship & \\
\hline $\begin{array}{l}\text { IDT 521: Online } \\
\quad \text { Learning ( } 3 \text { credits) }\end{array}$ & $\begin{array}{l}\text { Design: Message Design (1.2), Instructional Strategies (1.3) } \\
\text { Development: Computer-Based Technologies (2.3) } \\
\text { Management: Delivery System Management (4.3) }\end{array}$ & $\begin{array}{l}\text { 2. Teaching, learning, and } \\
\text { assessments; } 3 \text {. Digital age } \\
\text { learning environments }\end{array}$ & $\begin{array}{l}\text { Teaching Online Courses } \\
\text { Effectively }\end{array}$ \\
\hline $\begin{array}{l}\text { IDT 522: Video and } \\
\text { Media Production } \\
\text { ( } 3 \text { credits })\end{array}$ & $\begin{array}{l}\text { Development: Print Technologies (2.1), Audiovisual } \\
\text { Technologies (2.2), Computer-Based Technologies (2.3), } \\
\text { Integrated Technologies (2.4) }\end{array}$ & $\begin{array}{l}\text { 3. Digital age learning } \\
\text { environments }\end{array}$ & \\
\hline $\begin{array}{l}\text { LTD 600: Learning } \\
\text { Design Studio } \\
\text { ( } 3 \text { credits })\end{array}$ & $\begin{array}{l}\text { Design: ISD (1.1) Development: Integrated Technologies } \\
\text { (2.4) Management: Project Management (3.1) Evaluation: } \\
\text { Problem Analysis (5.1), Criterion-Referenced } \\
\text { Measurement (5.2), Formative Evaluation (5.3), } \\
\text { Summative Evaluation (5.4) }\end{array}$ & $\begin{array}{l}\text { 6. Content knowledge and } \\
\text { professional growth }\end{array}$ & \\
\hline
\end{tabular}

designers as part of their motive for choosing the program over the Master of Education options also available at the institution. $77 \%$ of alumni agree on some level (from somewhat agree to strongly agree) that "It was important to me that my professors are practitioners in the field." No participants disagreed with the statement.

Current students and graduates of the M.S. IDLT program continue to note how their instructors and courses speak to current digital learning trends and provide practical yet research-based experiences; they note how this prepares them to be successful in their current roles while also instilling confidence to pursue future ventures in the field. Specifically, $89 \%$ of alumni stated that they "Strongly Agree" with the statement that "My professors were knowledgeable about the subject matter." The researchers attribute such a strong response to the ability of the CIDL practitioners to speak to both the research and also the practice of the subject matter.

Faculty members agree even more strongly that it is "important [.. .] that students in the M.S. IDLT program are taught from working practitioners in the field of instructional design." In a recent survey of the six instructors in the program, $100 \%$ of faculty note that it is "Very Important." One faculty member noted, "Knowledge without continued practice becomes stale and static. Being a practitioner in some way keeps me grounded in applying what I know." As the faculty and alumni experiences support, the practitioner element is key in a program based on responding to an ever-changing digital and social environment such as the M.S. IDLT. Innovation hubs are home to practitioners that can be leveraged to offer such professional programming, but the undertaking must be thoughtful and intentional.

While there are other types of programs that make use of a practitioner-faculty role, such as teacher education (Trede and Smith 2012) and nursing (Mann and De Gagne 2017), the way M.S. IDLT practitioner-faculty are set-up as a supporting resource in addition to its role as leading an academic degree program sets this structure apart from others that are typically external partnerships. As will be discussed in a later section, further research and defining of structures and roles is needed to ensure the sustainability and quality of such programs as well as the responsibilities assigned as part of the innovation hub. 


\section{Role of Practitioner-Faculty in Professional Community Development}

As Instructional Design and Learning Technology professionals who are honing their own professional identities (Kilgore et al. 2019), M.S. IDLT faculty are participating in that growing professionalization process to the benefit of the program and students' community and network development. As mentioned previously, the staff in the CIDL are representative of this professionalization process in that they came from various academic and work experiences as they moved into instructional design roles. Their own professional community development that led to their ability to move into and success in instructional design roles informs the creation and coordination of this program. These experiences give the M.S. IDLT practitioner-faculty members greater insight into the competencies and skills required across the profession.

In addition to understanding and honing competencies related to their profession, instructional designers are also largely shaped by involvement in associations focused on practitioners, such as EDUCAUSE, the Online Learning Consortium (OLC), University Professional Continuing Education Association (UPCEA), the CBE Network (CBEN), and others. Further, many instructional designers are also involved in more scholarly-oriented associations, such as Association of Educational Communication and Technology, which have arms for practicing instructional designers while supporting research for the field. Instructional designers and leaders in the Center for Innovation and Digital Learning have active research agendas with publications and presentations in line with those expected of the university's full-time faculty.

The experiences of connecting and collaborating across the instructional design field to hone professional competencies and develop strong networks are evident in the design and facilitation of the MS IDLT program. M.S. IDLT instructors and leaders frequently receive positive feedback from both alumni and current students regarding the professional community development that occurs in the program. In fact, even the practitioner-faculty noted in a recent survey that they are "more connected and informed professional[s] in part because of M.S. IDLT." The M.S. IDLT program focuses on balancing instructor presence with student-to-student interaction as a way to develop this professional learning community. Four different free responses regarding the aspects that respondents enjoyed about the program in an alumni survey stressed how the aspect of community and connection to their peers was one of the strongest elements to the M.S. IDLT program. The importance of learning and creating relationships is fundamental to this program and its success, and the professionalization of the practitioner-faculty affords a unique approach to this element of the professional master's program.
Another area that has received a large amount of positive response is from the development of \#IDLTalks. The \#IDLTalks emerged from a student's suggestion and a desire to have opportunities to hear from those in the field, expanding the learning community to those within the professional community. \#IDLTalks use the networks of the faculty in the program to connect students to the larger profession. The \#IDLTalks have included individuals from across education, government, non-profit, and industry. Experiences like the \#IDLTalks and the resource sharing of their facultypractitioners are part of the reason $88 \%$ of alumni agree or strongly agree that there was a sense of community in the program and a student mentioned that they were able to connect with others in various fields. This is also part of the reason that faculty in the program report they feel more connected to the profession and the latest trends and issues.

\section{Organizational Advantages and Impact}

Finally, the experience of coordinating a program in the unique structure also has a positive impact on the instructional designers' work within the institution. These benefits range from trying out new approaches and technologies to seeing a variety of perspectives of the impact of instructional design work on students, faculty, and other stakeholders. In a recent survey, $83 \%$ of the M.S. IDLT faculty - who, again, are practitioners in the field - responded that their work with their faculty or clients is positively impacted by their involvement in the program, and that specifically, they share or use several ideas or tools from their experiences in the program. One respondent noted, "The level of confidence at which I work translates to clients/faculty who may have been resistant to fully online learning technologies."

Many of the successes and hurdles from offering our own program has influenced the instructional design team's work with faculty not only in sharing new ideas from experimentation but also in having more shared experiences. In the survey mentioned above, one faculty member noted, "It is much easier to explain best practices, pedagogies, and technology trends when I am actively using them myself. For instance, FlipGrid is much easier to explain when you use it often." $50 \%$ of faculty members specifically mentioned FlipGrid as an example of a successful experimentation. At the program design stage, the M.S. IDLT practitioner-faculty members were committed to using FlipGrid throughout the program. Each course has at least one FlipGrid in place of a textbased discussion. Noting that course evaluation comments frequently mentioned FlipGrid in a positive manner, the CIDL staff (home of most M.S. IDLT practitioner-faculty members) began encouraging faculty in other departments to try the tool and now offer regular training and support resources for the tool as a way to create more engaging online and blended courses across the university. 
As referenced earlier, one potential draw-back to the use of CIDL staff in teaching and coordinating a program was workload. Administrators were concerned about this as staff would be compensated as overload for their involvement in the program. However, recent M.S. IDLT faculty survey (conducted 1.5 years into the program) had $50 \%$ of faculty stating that teaching in the program positively impacts their workload and $50 \%$ noted it neither positively nor negatively impacted their workload. One faculty member noted, "It is definitely more work, but that is to be expected when taking on courses." Another faculty member echoed a similar sentiment, "It is a give and take." While the practitioner-faculty members are realistic about the workload, several highlighted that it helps them focus on "innovative practices" and encourages them to be "more curious," which in turn strengthens the CIDL's work with faculty members at the institution.

While program leaders pay careful attention to workload and balance to avoid burnout and the loss of the aforementioned advantages, there are still elements of impact on the organization that need should be addressed when approaching the development of such an innovative program. While Anderson University is known as a nimble and agile institution that afforded the opportunity to create the M.S. IDLT program, further examination is even needed around issues of policy, governance, and sustainability that are built into traditional academic units but not support units that now manage an external offering such as a degree program.

\section{Implications \& Future Research}

Universities frequently partner with hospitals, school districts, and other entities in offering programs as described in the practitioner-faculty section above, the unique situation of having a degree-granting program of a university partner with its own support unit to manage a program instead of in a traditional academic unit presents opportunities for further research. Due to the exclusivity of this program design and with only one similar program found in Georgetown University's (n.d). master's degree program in Learning, Design, and Technology (LDT), research and data are lacking regarding such programs.

As discussed in the sections above, more research is needed on how best to structure and categorize such innovative degree granting programs. Specifically, internal partnerships of innovation hubs need examination to determine how they can serve gaps in academic offerings yet effectively maintain their support functions within the university as discussed. This is an important element to ensuring the sustainability and quality of such unique programs. While living outside of a traditional academic unit presents opportunities and affordances, institutional structures and policies exist so that programs can survive personnel changes. Thus, research should be conducted to allow for flexible yet sustainable programs of this nature in using practitioner-faculty in innovation hubs and for models that scale across the various types of institutions in the higher education ecosystem.

While this program is not unique in having practitioners in the field teach courses, there was a lack of research on the use of this model in other programs. When researching similar program structures, there was a gap in the articles that highlighted the role of practitioner- faculty. Instead "clinicalfaculty" was located within the research and often within teacher education (Trede and Smith 2012) or nursing (Mann and De Gagne 2017). Nevertheless, it should be noted that these clinical-faculty members were often mentioned in regard to student teaching, teacher observation, or clinical nursing rotations. Consequently, when the role practitioner-faculty was examined the authors were left with an absence of research to examine. Thus, more research is needed which explores programs with practitioner-faculty and the effectiveness of this teaching approach both inside and outside of instructional design and technology. If programs are looking to prepare their graduates for careers, practitioners within the field teaching about the field bring great advantages.

In addition to the unique role of the practitioner-faculty members, external relationships of programs such as the M.S. IDLT are necessary to ensure research around effectiveness and that outcomes are captured at a macro level. For example, the external partnerships between innovation hubs and school districts, businesses, and other entities who benefit from an innovation hub's programming need to be involved in more formalized expectations such as those that exist in the National Association of Professional Development Schools (NAPDS). While the programming described in this case study did not approach the development using a PDS framework, it would be worthwhile to add to this gap in innovation hubs and school partnerships in the PDS literature given the goal of such networks to formalize ad-hoc partnerships.

Finally, the M.S. IDLT program fits the characteristics of professional master's program, but further research is needed on the implications or possibilities of classification as a professional science master's given the unique educational and technological focus. ${ }^{1}$ The professional master's format has largely been found in business and education, but in the last decade, STEM disciplines have taken steps to professionalize their programs given the needs of employers and data that finds many masters of science students find themselves working outside of academia (National Research Council 2008). The M.S. IDLT program would not consider itself strictly an

\footnotetext{
${ }^{1}$ A professional master's degree is distinct from a classical or applied program according to the typologies described by the Council of Graduate Schools, and it "often includes activities and relationships that cross the boundaries between departments and between the university and employers. An active interaction with potential employers provides opportunities for skills development, experience, and contacts that are closely aligned with marketplace demand" (Council of Graduate Schools 2006).
} 
education program given its unique combination of having an education and computational focus in the M.S. IDLT degree, but it may speak to a call from the National Research Council (NRC) to develop professional science master's program for educators involved in STEM areas. The implications of having a professional science master's program with an education angle, particularly K12 in the case of the M.S. IDLT program, could present new additions to the marketplace for educators to upskill or re-skill to serve their organizations in their digital transformation initiatives, but it warrants further research to help frame conversations around such programs.

\section{Conclusion}

Colleges and schools of education serve K12 educators very well in many areas and there are instructional design programs housed in traditional academic units produce high-caliber scholars and researchers that impact our field. However, this article suggests that partnerships between university innovation hubs and K12 schools fill a gap of programming focused on developing practical skills related to digital transformation of learning environments. Such programming would be comprised of practitioner-faculty outside of traditional academic structures. Few programs exist like the M.S. IDLT program described in this article or the Georgetown University (n.d.) Center for New Designs in Learning and Scholarship's practitioner-based degree in Learning, Design, and Technology. Georgetown's program describes a focus on higher education professionals, and Anderson University's program draws an overwhelming majority of K12 educators, but both are focused on using practitioner-faculty to prepare future practitioners to transform teaching and learning environments.

There is indeed further research needed around operating a program with practitioner-faculty housed in an innovation hub yet outside of a traditional academic unit. These challenges range from internal to external. However, there are benefits to attempting such structural shifts to allow more universities to experiment with program offerings in their innovation hubs. These centers then expand their reach from not only the university, but also as a hub for educational innovation for their community and regions. Further, there is evidence that involve practitioner-faculty in such offerings around digital transformation of learning environments is needed to ensure relevant and well-equipped for today's learning design and technology needs.

\section{Compliance with Ethical Standards}

The majority of information for this manuscript was obtained directly from the authors who are the Program Director and Assistant Program Director. They used their experiences and documents that were used in planning and maintaining the program. However, it should be noted that some information was acquired through current faculty members and alumni perspectives.
All general feedback and perspectives were gleamed from the alumni survey that was emailed out to students upon completion of their classes in the program. The first set of students received their survey for general program feedback. Upon checking with the IRB board, in order to use data acquired from the alumni survey, we were instructed that IRB approval was not necessary because it adheres to the "exempt status" as it examines the perspectives of students about the program, course work, faculty, etc. Upon receiving this notification, the authors used both the first and second group of alumni as well as faculty results in reporting feedback for this manuscript.

All quotes that were used in the manuscript were obtained from student and faculty responses from the two surveys.

\section{References}

Allen, E., \& Seaman, J. (2017). Digital learning COMPASS: Distance education enrollment report 2017 [Report]. Babson Survey Research Group. Retrieved June 26, 2020, from https://onlinelearningsurvey. com/reports/digtiallearningcompassenrollment2017.pdf.

Bishop, M.J. \& Keehn, A. (2015). Leading academic change: An early market scan of leading-edge postsecondary academic innovation centers [Report]. University System of Maryland. Retrieved June 26, 2020, from https://www.educause.edu/sites/default/files/library/ presentations/E15/PS11/LeadingAcademicChangeProjectReport. pdf.

Bureau of Labor Statistics. (2020). 2016-17 edition, instructional coordinators. U.S. Department of Labor, Occupational Outlook Handbook. Retrieved June 26, 2020, from https://www.bls.gov/ ooh/education-training-and-library/instructional-coordinators.htm.

Campbell, A. (2015). Upstate schools go high-tech. Greenville News. Retrieved June 26, 2020, from https:/www.greenvilleonline.com/ story/life/family/parent/2015/07/31/upstate-schoolsgo-high-tech/ 30937173/.

Chang, H., Ngunjiri, F. W., \& Hernandez, K. C. (2013). Collaborative autoethnography. London, UK: Routledge.

Cortez, M.B. (2016). Q\&A: Georgetown University's Eddie Maloney helps pave the way for the future of ed tech. EdTech. Retrieved Sept. 20, 2020, from https://edtechmagazine.com/higher/higher/ k12/article/2016/12/qa-georgetown-universitys-eddie-maloneyhelps-pave-way-future-ed-tech.

Council of Graduate Schools. (2006) Professional master's education: A CGS guide to establishing programs. Washington, DC: Council of Graduate Schools, 43-44.

Creswell, J. W., \& Plano Clark, V. L. (2011). Designing and conducting mixed methods research. SAGE Publications.

Education Week. (2020). Map: Coronavirus and school closures. Retrieved June 26, 2020, from https://www.edweek.org/ew/ section/multimedia/map-coronavirus-and-school-closures.html.

Fyle, C. O., Moseley, A., \& Hayes, N. (2012). Troubled times: The role of instructional design in a dual-mode university? Open Learning, 27(1), 53-64. https://doi.org/10.1080/02680513.2012.640784.

Georgetown University (n.d.) Design the future of learning. Georgetown University: Learning, Design, Technology. Retrieved Sept. 20, 2020, fromhttps://ldt.georgetown.edu/.

Gonzalez, J. [@cultofpedagogy]. (2020).WTF moment: The day I learned about a field of study called instructional design that somehow had no relationship with [tweet]. Twitter. https:/twitter.com/ cultofpedagogy/status/1222157075180138496

Hains-Wesson, R., \& Young, K. (2017). A collaborative autoethnography study to inform teaching of reflective practice in STEM. Higher Education Research \& Development, 26(2), 297 310. https://doi.org/10.1080/07294360.2016.1196653.

Kilgore, W., Prusko, P., \& Gogia, L. (2019). A snapshot of instructional design: Talking points for a field in transition. EDUCAUSE 
Review. Retrieved June 26, 2020, fromhttps://er.educause.edu/ blogs/2019/8/a-snapshot-of-instructional-design-talking-points-fora-field-in-transition.

Mancilla, R. \& Frey, B. (2020). A model for developing instructional design professionals for higher education through apprenticeship: Blending theory and practice. The Journal of Applied Instructional Design, 9(2). Retrieved July 15, 2020 from https://edtechbooks.org/ jaid_9_2/a_model_for_developi

Mann, C., \& De Gagne, J. C. (2017). Experience of novice clinical adjunct faculty: A qualitative study. The Journal of Continuing Education in Nursing, 48(7), 167-175. https://doi.org/10.3928/ 00220124-20170321-07.

Merriam, S. B. (1998). Qualitative research and case study applications in education. Jossey-Bass.

NAPDS, National Association for Professional Development Schools (n.d.). 9 essentials. NAPDS.org. Retrieved Nov. 16, 2020, from https://napds.org/nine-essentials/.

National Research Council. (2008). Science professionals: Master's education for a competitive world. Washington, DC: The National Academies Press. https://doi.org/10.17226/12064.

Picciano, A. G. \& Seaman, J. (2007). K-12 Online Learning: A survey of U.S. school district administrators [Report]. Sloan-C. Retrieved June 26, 2020, from https://www.onlinelearningsurvey.com/ reports/k-12-online-learning.pdf.

Poovey, B. (2016). Greenville County schools rolling out one-to-one computing. GSA Business Report. Retrieved June 26, 2020, from https:/gsabusiness.com/news/education/70213/\#: :text=Students\% 20at $\% 2010 \% 20$ Greenville $\% 20$ County, $16 \% 20$ for $\% 20$ use $\% 20$ at $\%$ 20school.

Shaffer, D. W., Nash, P., \& Ruis, A. R. (2015). Technology and the new professionalization of teaching. Teachers College Record, 117, 130 Retrieved July 15, 2020 from https://www.andrewruis.com/wpcontent/uploads/2015/12/Technology-and-the-NewProfessionalization-of-Teaching.pdf.

Smith, S. (2011). Instructional designers as leaders in professional learning communities: Catalysts for transformative change. Academic Leadership, 9(4), 1-11.

Taylor, M., Klein, E. J., \& Abrams, L. (2014). Tensions of reimagining our roles as teacher educators in a third space: Revisiting a co/ autoethnography through a faculty lens. Studying Teacher Education, 10(1), 3-19. https://doi.org/10.1080/17425964.2013. 866549.

Trede, F., \& Smith, M. (2012). Teaching reflective practice in practice settings: Students' perceptions of their clinical educators. Teaching in Higher Education, 17(5), 612-627. https://doi.org/10.1080/ 13562517.2012.658558.

Wilcox, K. E., Sarma, S., \& Lippel, P. H. (2016). Online education: A catalyst for higher education reforms (Final Report) [Report]. Massachusetts Institute of Technology, Online Education Policy Initiative. Retrieved June 26, 2020, from https://oepi.mit.edu/files/ 2016/09/MIT-Online-Education-Policy-Initiative-April-2016.pdf.

Publisher's Note Springer Nature remains neutral with regard to jurisdictional claims in published maps and institutional affiliations. 